\title{
Low Voltage Ride through Control Capability of a Large Grid Connected PV System Combining DC Chopper and Current Limiting Techniques
}

\author{
Ronald Ntare, Nabil H. Abbasy, Karim H. M. Youssef \\ Department of Electrical Power \& Machines Engineering, Faculty of Engineering, Alexandria University, Alexandria, Egypt \\ Email: ntareron20@gmail.com, abbasyna@hotmail.com, Khmyoussef@yahoo.com
}

How to cite this paper: Ntare, R., Abbasy, N.H. and Youssef, K.H.M. (2019) Low Voltage Ride through Control Capability of a Large Grid Connected PV System Combining DC Chopper and Current Limiting Techniques. Journal of Power and Energy Engineering, 7, 62-79.

https://doi.org/10.4236/jpee.2019.71004

Received: December 10, 2018

Accepted: January 18, 2019

Published: January 21, 2019

Copyright $\odot 2019$ by author(s) and Scientific Research Publishing Inc. This work is licensed under the Creative Commons Attribution International License (CC BY 4.0).

http://creativecommons.org/licenses/by/4.0/

(c) (i) Open Access

\begin{abstract}
This paper presents the development and performance capability of a comprehensive Low voltage ride through (LVRT) control scheme that makes use of both the DC chopper and the current limiting based on the required reactive power during fault time. The study is conducted on an 8.5 MW single stage PV power plant (PVPP) connected to the Rwandan grid. In the event of fault disturbance, this control scheme helps to overcome the problems of excessive DC-link voltage by fast activation of the DC chopper operation. At the same instance, AC current is limited to the maximum rating of the inverter as a function of the injected reactive current. This helps overcome AC-overcurrent that may possibly lead to damage or disconnection of the inverter. The control scheme also ensures voltage support and power balance through the injection of reactive current as per grid code requirements. Selected simulations using MATLAB are carried out in the events of different kinds of fault caused voltage dips. Results demonstrate the effectiveness of the proposed LVRT control scheme.
\end{abstract}

\section{Keywords}

Grid Connected Photovoltaic (PV) Power Plants (GCPSs), Voltage Dips, Low Voltage Ride Through (LVRT), Grid Code (GC)

\section{Introduction}

Grid connected Photovoltaic (PV) systems have become the most important source of renewable energy in modern power systems [1]. Previously, when PV systems were poorly diffused and the appropriate standards and industrial codes required by the distribution system operators were not in force, the focus was on 
the protection tripping when grid voltage variations occurred [2]. In [3], studies focused on the effects of power quality issues regarding GCPSs and the protection of different topologies of PV inverter during disturbances. It was always a requirement for the inverter to disconnect directly to avoid the islanding problem [3]. Now days, with the increasing PV systems penetration levels into the power system, the disconnection with grid during disturbances is no longer feasible as it can lead to stability, reliability and operation problems [4] [5]. The technological advancement in power systems has enabled the elaboration of specific technical requirements for the connection of PV power plants (PVPPs) into the existing power grids. Fault ride through at both low and high voltages is one of the mandatory requirements of the PVPPs. Majority of the system disturbances such as faults occur at the low voltage side of the interconnected power system. Therefore, of recent the LVRT requirement has been widely developed and integrated in the modern grid codes. In compliance with the requirement the PVPP withstand grid voltage dips to a certain percentage of the nominal voltage (down to 0 in some GCs) for a specific duration as depicted in Figure 1 [1] [6]. Area A represents the nominal operating voltage at the point of common coupling (PCC), where the PVPP works continuously. Within area B, the PVPP has to withstand the voltage dip and remain connected to the system for a period of time $\left(t_{\mathrm{o}} \rightarrow t_{1}\right)$. Otherwise, it will be disconnected. Upon recovery of the PCC voltage in area C to $V_{1}$ within time $t_{2}$, the PVPP remains under continuous operation without disconnection. The values of $V_{\mathrm{o}}, V_{1}, t_{1}$, and $t_{2}$ differ from one GC to another based on the standards and characteristics of the national grid. Several countries have developed and implemented LVRT into grid code connection requirement. In this work, the LVRT requirements for large-scale GCPSs have been adopted from the German grid code [6]. The requirement stipulates that the PVPP must not disconnect from the grid for $150 \mathrm{~ms}$ when the line voltage ( $V$ ) drops to $0 \%$ of the nominal voltage $\left(V_{n}\right)$. Furthermore, the voltage should recover $90 \%$ from its pre-fault value within 0.15 seconds from the occurrence of the voltage dip. This not only keeps the inverter connected, but also supports the grid voltage recovery through injection of reactive power.

Fault caused voltage dips are considered as one of the most frequent and

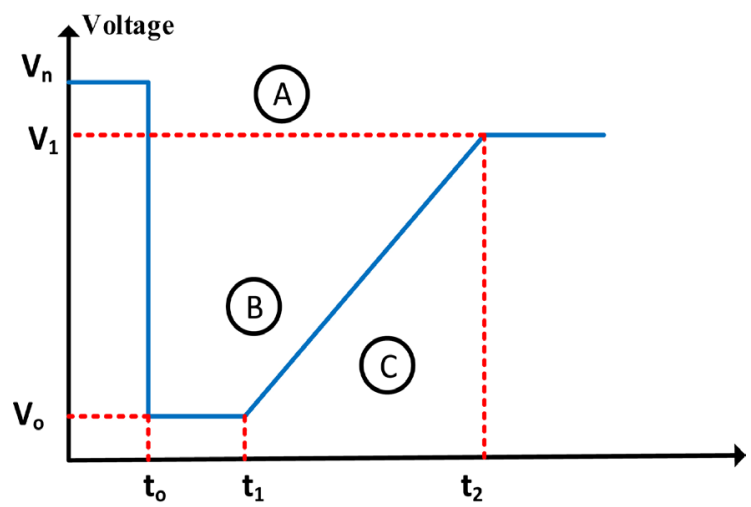

Figure 1. General curve limits for low-voltage ride through requirements [1] [4]. 
harsh power quality events due to its effects on various power system components [7]. During such events, two major problems arise i.e. the first one involves dealing with the over voltage at the inverter's DC side and an over current at the AC side while the second one deals with the injection of reactive current, considered as a solution to voltage recovery and support [8]. In the study of GCPSs, existing LVRT control strategies with dynamic voltage support (injection of reactive power), have been carried out on two-stage inverter based GCPSs. A method that applied the reactive power injection for GCPS based-on-German GC using-super capacitor energy-storage-system (SCESS) was proposed in [9].

The SCESS is connected-to-the-system via bi-directional buck-boost converter and then to dc-link in which it provides the grid with-both-active and-reactivepower using specific control in order to support utility-grid-during-the fault. But this control not only increases the-cost-but-also-effects the reliability of the system [8] [9]. A probabilistic fuzzy neural network intelligent control to regulate and control the reactive power value under grid faults was also proposed in [10]. The above control methods inject reactive current during voltage dips. However, the issue of power balance and inverter protection during faults is not well addressed. In the application of single stage inverter based GCPS, less publications have addressed the prevention of excessive rise in DC link voltage, thus protecting the inverter as well as providing reactive power support to the grid.

In view of the above discussion, this paper presents a comprehensive LVRT control strategy that suppresses the excessive DC voltage and AC current as well as injecting reactive power for grid support during fault caused voltage dips. The study is demonstrated on a realistic model of a single stage three phase PVPP (8.5 MW) connected to the Rwandan grid under grid fault conditions. The LVRT requirement is adopted from the German GC for grid support. Selected simulation results present the effectiveness of the control strategy.

\section{Design of a Single Stage PVPP}

The grid connected single-stage PV system under this study consists of different power stages as shown in Figure 2. It includes the PV array, maximum power point tracking (MPPT) technique, the dc-link capacitors, the three phase voltage source inverter (VSI), LC filter and the step up transformer at the point of common coupling with the distribution side of the grid. Modelling of the above-mentioned power stages is explained below.

\subsection{PV Module Modeling}

Figure 3 shows an equivalent circuit of the PV module, which consist of several PV cells. The output current and voltage relationship of PV module can be expressed using the following equations [11] [12].

$$
\begin{gathered}
I_{p h}-I_{d}-I_{p}-I_{L}=0 \Rightarrow I_{L}=I_{p h}-I_{d}-I_{p} \\
\left(V_{d}=V_{p}\right)=V_{S}+V_{L} \Rightarrow V_{d}=R_{S} I_{L}+V_{L}
\end{gathered}
$$




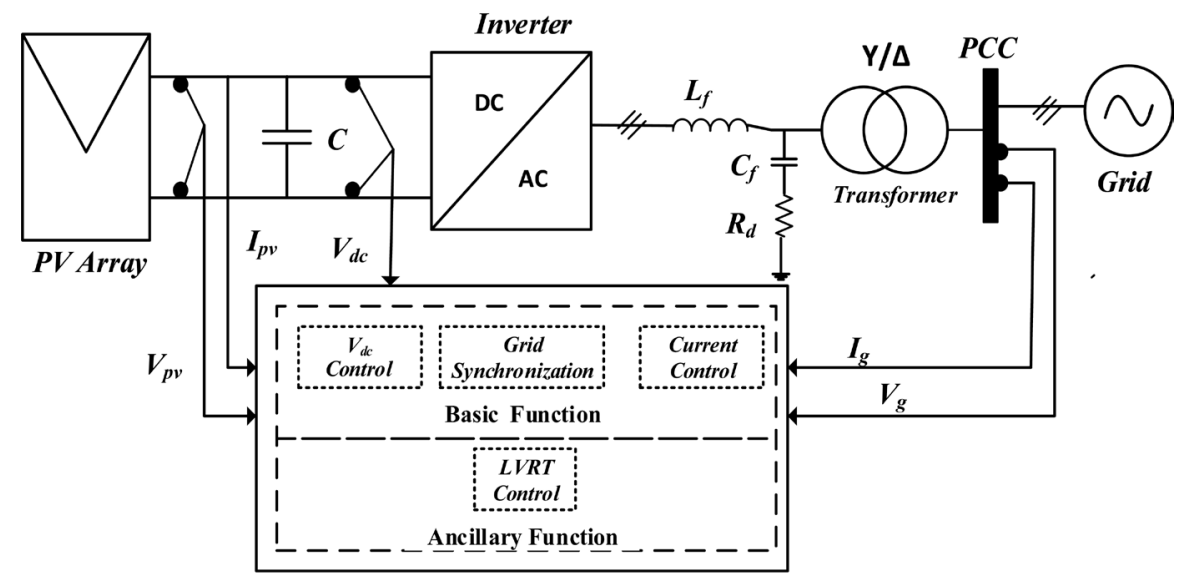

Figure 2. Structure of a single stage three-phase grid connected PV-system.

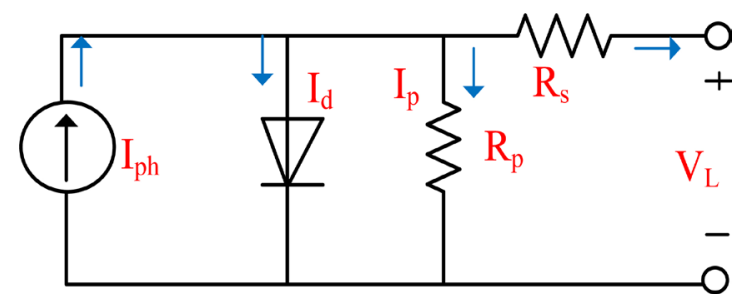

Figure 3. Equivalent circuit of a solar cell.

where $I_{p}=\frac{V_{p}}{R_{p}}=\frac{V_{d}}{R_{p}}$, substitute $V_{d}$ from (2)

$$
I_{p}=\frac{I_{L} R_{s}+V_{L}}{R_{p}}
$$

The diode current can be expressed as follows [11] [13].

$$
I_{d}=I_{s a t}\left(\mathrm{e}^{\left(V_{d} / m N_{s} V_{T}\right)}-1\right)
$$

$V_{T}=\frac{K T}{q}$, substitute by $V_{T}$ in (4), consequently

$$
I_{d}=I_{s a t}\left(\mathrm{e}^{\left(V_{d} / m N_{s} K T\right)}-1\right)
$$

By substituting Equations (3) and (5) in (1), the load current can be written as below;

$$
I_{L}=I_{p h}-I_{s a t}\left(\mathrm{e}^{\left(q V_{d} / m N_{s} K T\right)}-1\right)-\frac{I_{L} R_{s}+V_{L}}{R_{p}}
$$

where $I_{p h}, I_{d}, I_{p}$ and $I_{s a t}$ are the photo current, diode current of the PV cell, shunt current, and the reverse saturation current of the solar module, respectively. $N_{s}$ is the number of cells connected in series, $V_{T}$ is the thermal voltage and equals to $25.7 \mathrm{~V}$ at $25^{\circ} \mathrm{C}$ and $\mathrm{m}$ is the ideality factor of the diode $\left(1-5\left[V_{T}\right]\right) . K$ is the Boltzmann constant $\left(1.381 \times 10^{-23} \mathrm{~J} / \mathrm{K}\right)$ and $q$ is the charge of the electron $\left(1.6021 \times 10^{-19}\right) . R_{s}$ and $R_{p}$ are the equivalent series and parallel resistance of the solar module, respectively. $I_{p h}$ is affected by sun irradiance and temperature. The 
influences of these two factors can be expressed by the following equation [14].

$$
I_{p h}=\left[I_{s c}+\alpha_{i}(T-25)\right] \frac{G}{G_{r e f}}
$$

$I_{p h}$ represents the photocurrent at nominal PV standard tests condition (STC, normally $25^{\circ} \mathrm{C}$ and $1000 \mathrm{~W} / \mathrm{m}^{2}$ ) for temperature and irradiation. $I_{s c}$ is the nominal short circuit current of the module. $G$ and $G_{\text {ref }}$ are the amount of actual and nominal irradiation, respectively. $T$ is the temperature degree in kelvin and $\alpha_{i}$ is the current temperature coefficient. The $I_{s a t}$ and $I_{s c}$ can be obtained according to the following equations [12].

$$
\begin{gathered}
I_{s c}=I_{s c, r e f}\left(\frac{R_{P}+R_{S}}{R_{P}}\right) \\
I_{s a t}=\frac{I_{s c, r e f}+\alpha_{i}(T-25)}{\mathrm{e}^{q\left(V_{o c, r e f}+\alpha_{v}(T-25) / N_{s} m K T\right)-1}}
\end{gathered}
$$

$I_{s c, r e f}$ and $V_{o c, r e f}$ are the short circuit current and open circuit voltage of the module at STC, respectively, whereas $\alpha_{y}$ is the open circuit voltage temperature coefficient. These values are evaluated by the manufacturer as presented in Table 1. The output voltage and current of the module will be represented as follows,

$$
I_{L}=\left[I_{s c}+\alpha_{i}(T-25)\right] \frac{G}{G_{r e f}}-I_{s a t}\left(\mathrm{e}^{\left(q V_{d} / m N_{s} K T\right)}-1\right)-\frac{I_{L} R_{s}+V_{L}}{R_{P}}
$$

\subsection{PV Array Sizing of the PVPP}

The sizing of the proposed PV plant to generate a peak power of $8.5 \mathrm{MW}$ is accomplished with 20 series modules and 1418 parallel strings. Table 2 shows the theoretical calculation results of the designed PV array at STC.

\subsection{PV Control System during Normal Operation}

The inverter is the most important equipment in the control structure of grid connected PV system. In this work, a voltage source inverter (VSI) is used for power conversion and control purposes. The DC-link voltage of the inverter is set at a value $719.4 \mathrm{~V}$, a value equal to the maximum output voltage of the Array.

Table 1. BYD 300P6C-36 PV module parameters at STC.

\begin{tabular}{cc}
\hline Parameter & Value \\
\hline Maximum Output power at STC $\left(P_{\max }\right)$ & $300 \mathrm{~W}$ \\
Open circuit voltage $\left(V_{O C}\right)$ & $45.19 \mathrm{~V}$ \\
Short circuit current $\left(I_{S C}\right)$ & $8.83 \mathrm{~A}$ \\
Maximum power point voltage $\left(V_{m p}\right)$ & $35.97 \mathrm{~V}$ \\
Maximum power point current $\left(I_{m p}\right)$ & $8.34 \mathrm{~A}$ \\
Number of cells $\left(N_{S}\right)$ & 72 \\
\hline
\end{tabular}


This is to reduce the current ripple and regulate the voltage of the DC side of the inverter. In normal operation, the control system is as depicted in Figure 4. System design parameters were obtained from the network operator of the system

Table 2. Theoretical calculation results of the designed PV array.

\begin{tabular}{cc}
\hline Parameter of the PV Array & Value \\
\hline Number of strings $\left(N_{P V s}\right)$ & 1418 \\
Number of series modules $\left(N_{P V S}\right)$ & 20 \\
Maximum current $\left(I_{m P V}\right)$ & $N_{P V s t} \times I_{m p}=11,826.2 \mathrm{~A}$ \\
Maximum voltage $\left(V_{m P V}\right)$ & $N_{P V s} \times V_{m p}=719.4 \mathrm{~V}$ \\
DC Output power $\left(P_{d c}\right)$ & $V_{m P V} \times I_{m P V}=8.507 \mathrm{MW}$ \\
Open Circuit-voltage $\left(V_{P V_{-} O C}\right)$ & $N_{P V s t} \times V_{O C}=903.8 \mathrm{~V}$ \\
Open Circuit-current $\left(I_{P V_{-} O C}\right)$ & $N_{P V} \times I_{S C}=12,520.94 \mathrm{~A}$
\end{tabular}

Table 3. System design parameters.

\begin{tabular}{cc}
\hline Parameter Description & Value \\
\hline Inverter size, $P_{i n v}$ & $8.5 \mathrm{MVA}$ \\
Inverter voltage, $V_{t}$ & $400 \mathrm{~V}$ \\
DC-Link capacitance, $C_{d c}$ & $2 * 359.7 \mathrm{~V}$ \\
Frequency of Grid Supply, $f s$ & $50 \mathrm{~Hz}$ \\
Switching Frequency of inverter & $20 \mathrm{kHz}$ \\
Inductance of the Harmonic filter, $L_{f}$ & $6.94 \mu \mathrm{L}$ \\
Capacitance of the Harmonic filter, $C_{f}$ & $8.45 \mathrm{mF}$ \\
Damping resistor, $R_{d}$ & $4.24 \mathrm{e}-4 \Omega$ \\
Coupling transformer ratio, $X_{1}$ & $0.4 / 15 \mathrm{kV}$
\end{tabular}

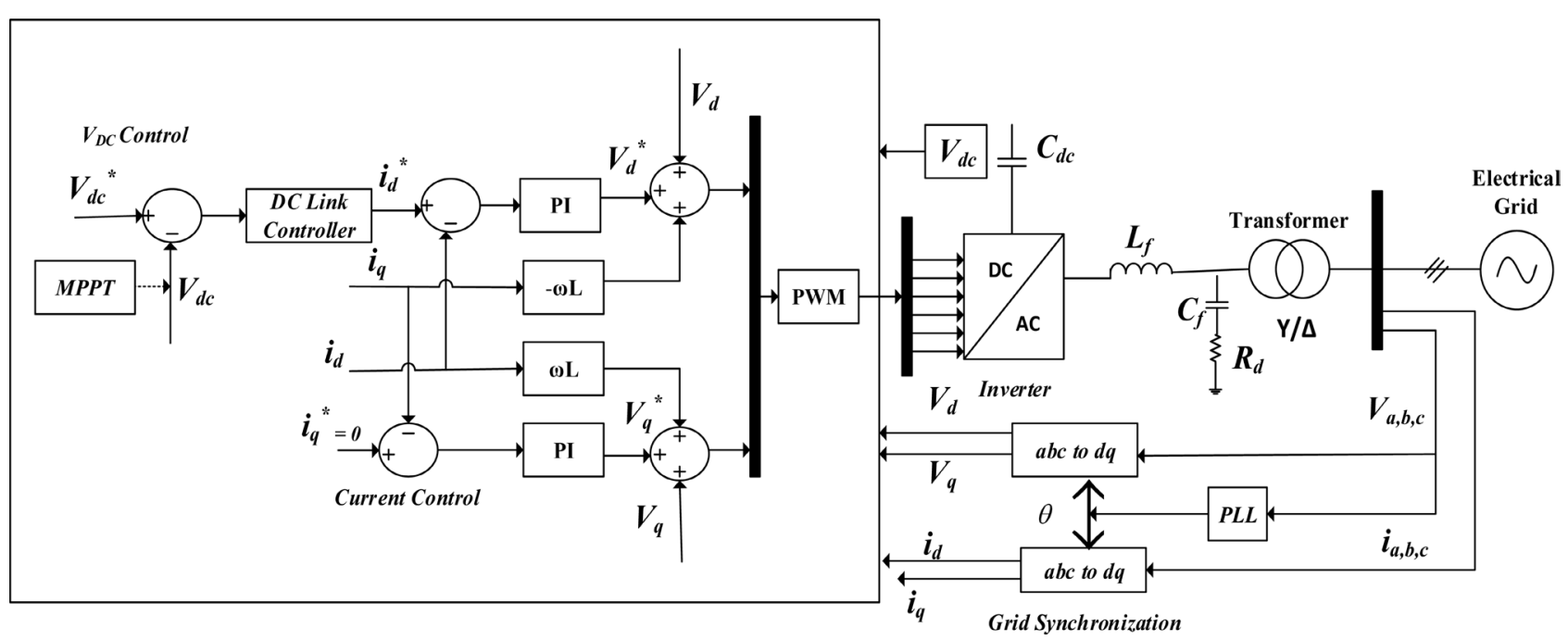

Figure 4. Schematic diagram of the control scheme of the three-phase inverter in normal operation. 
under study, results are tabulated in Table 3. The control system is made up of the current loop used to regulate the grid current and is responsible for the protection and power quality issues [15]. The DC link voltage loop to control $V_{d c}$ level, necessary for the active power balancing in the system. The output of this loop is used as an active current reference $\left(i_{d}^{*}\right)$ whereas the reactive current reference $\left(i_{q}^{*}\right)$ is normally set to zero for a unity power factor. This indicates that the system only produces active power. Grid voltage and phase angle synchronization is achieved with the phase locked loop (PLL) based on (d-q) synchronous reference frame (SRF-PLL) $\theta_{\mathrm{PLL}}$ is obtained through the SRF-PLL that is used for $a b c$ to dq0 transformation as shown in (11) and (12) where $\mathrm{f}$ can be either three phase voltage or current. The inner loop PI controllers of VSI control mode produce active voltage reference $\left(\left(V_{d}\right)\right.$ and reactive voltage reference $\left(V_{q}\right)$. Active and reactive voltage references are used for $\mathrm{dq} 0$ to $\mathrm{abc}$ transformation in order to get $V_{a b c}$ Lastly, $V_{a b c}$ is sent to PWM signal generator to obtain switching pulses for the VSI.

$$
\begin{aligned}
& {\left[\begin{array}{l}
f_{\alpha} \\
f_{\beta}
\end{array}\right]=\frac{2}{3}\left[\begin{array}{ccc}
1 & -\frac{1}{2} & -\frac{1}{2} \\
0 & \frac{\sqrt{3}}{2} & -\frac{\sqrt{3}}{2}
\end{array}\right]\left[\begin{array}{l}
f_{a} \\
f_{b} \\
f_{c}
\end{array}\right]} \\
& {\left[\begin{array}{l}
f_{d} \\
f_{q}
\end{array}\right]=\left[\begin{array}{ll}
\cos \theta^{\prime} & \sin \theta^{\prime} \\
-\sin \theta^{\prime} & \cos \theta^{\prime}
\end{array}\right]\left[\begin{array}{l}
f_{\alpha} \\
f_{\beta}
\end{array}\right]}
\end{aligned}
$$

Subsequently, the maximum active and reactive power flowing through the inverter can be calculated as below;

$$
\begin{gathered}
P=\frac{3}{2}\left(V_{d} i_{d}\right) \\
Q=\frac{3}{2}\left(-V_{d} i_{q}\right)
\end{gathered}
$$

\section{The Study System: Rwandan Electrical Distribution System}

The system under study is part of the of the Rwandan distribution system. In Rwanda, the distribution system as described in the Rwanda Grid Code covers a system of electrical lines with voltage from $30 \mathrm{kV}$ and below [16]. The PVPP is connected to the grid through a $15 \mathrm{kV}$ distribution line $10.8 \mathrm{~km}$ away to a step down substation connected to the $110 \mathrm{kV}$ high voltage network through a 10 MVA. At the substation there are 4 T-OFF feeders supplying a series of main distribution substation (MDS) and loads. In the model, these have been aggregated into one load of 6.5 MW and 1.5 Mvar as clearly shown in Figure 5.

\section{Proposed LVRT Control Strategy during Abnormal Conditions}

In a single-stage, three phase GCPS, the active power is controlled by regulating 
voltage of the dc-link capacitor during normal operation in order to extract the maximum power from the PV array. When a fault occurs, an imbalance occurs between the incoming power from the PV side and the power delivered to the electrical grid. This leads to transient excessive voltage at dc-side, and over-current at ac-side. In Figure 6, a combined control scheme is proposed to protect the DC accessories from excessive DC voltage and ac current while keeping the PVPP connected to the host power system. The proposed strategy uniquely makes use of a quick fault detection algorithm, combines DC chopper braking circuit, reactive current injection and active current limiting techniques. This also provides grid support through injection of reactive and active power based on the level of voltage dips. Upon occurrence of the fault, the fault is detected using a switching algorithm based on the threshold of the DC link voltage, the threshold $V_{d c}$ value is $725 \mathrm{~V}$ compared to the nominal $V_{d c}=719.4 \mathrm{~V}$ [17]. The LVRT mode is switched on whenever the threshold value is exceeded as shown in the algorithm in Figure 7. The DC-chopper braking circuit and the current limiting technique operate in parallel. However, the DC chopper circuit leads to absorb the excessive energy. Each LVRT control technique is described in the sections below.

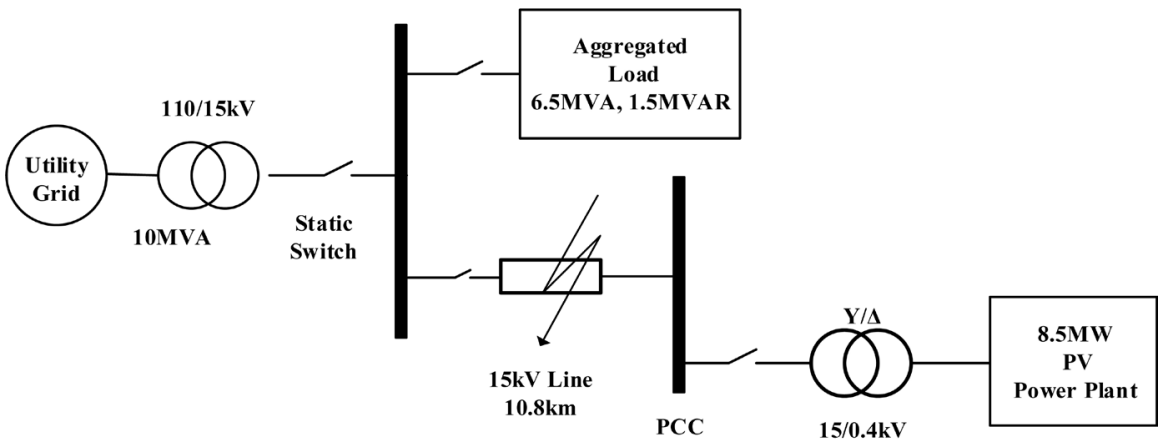

Figure 5. The Single line diagram for the study system.

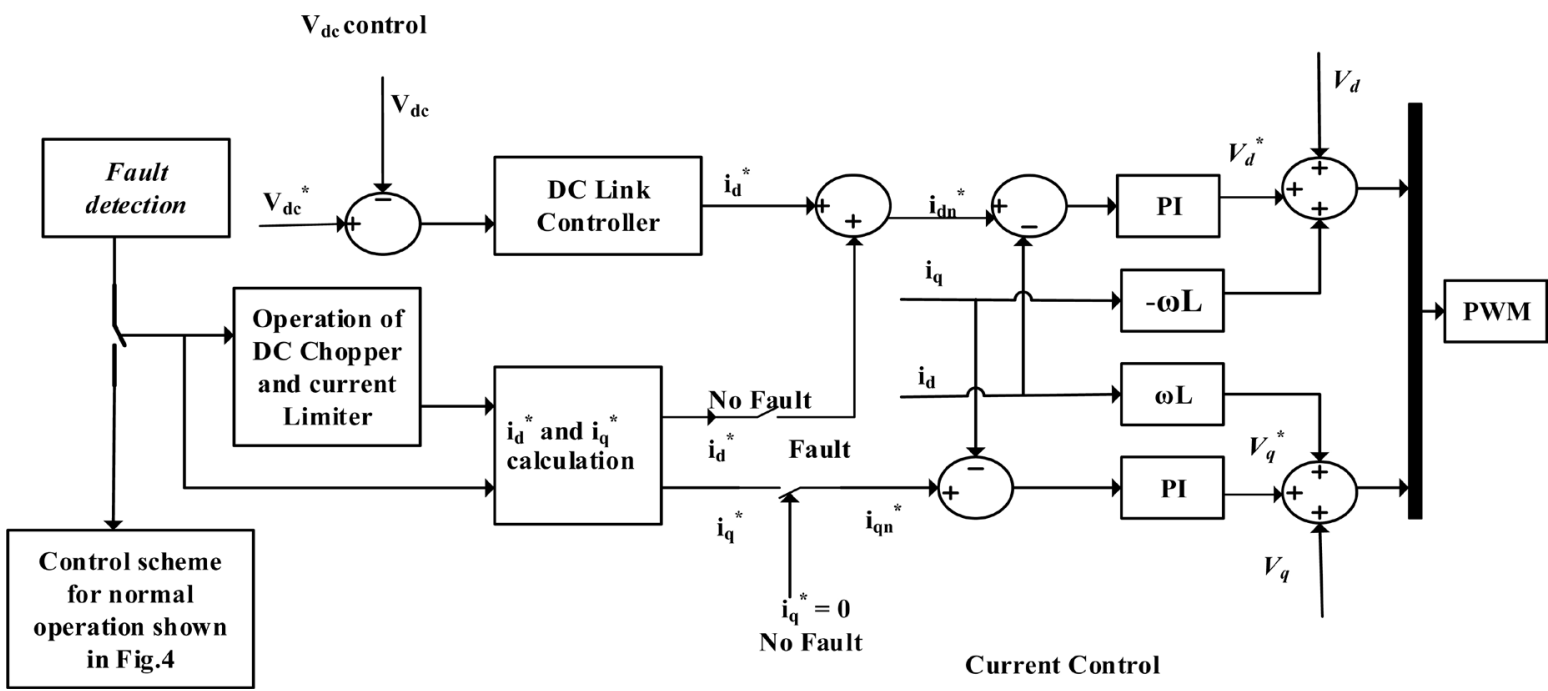

Figure 6. Schematic diagram for the proposed of the proposed LVRT control scheme. 


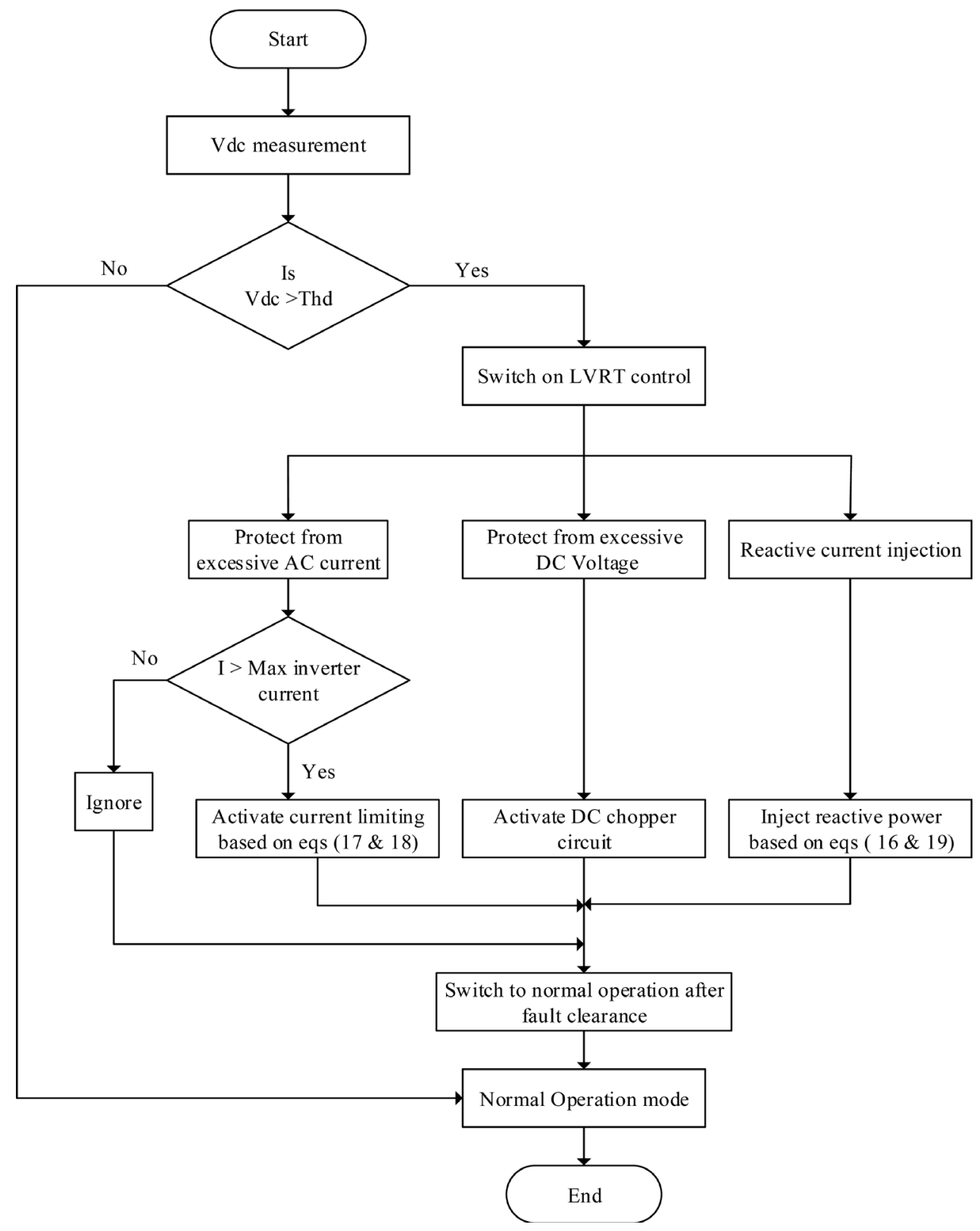

Figure 7. Flow chart for the operation of the proposed LVRT control scheme.

\subsection{Braking Chopper for Excessive DC Voltage Protection}

During a fault caused voltage dip, the voltage of dc-link $\left(V_{d c}\right)$ increases momentarily due to sudden drop in active power supplied by the PV system [18]. This will lead to rapid increase in power output of PV system, which may cause damage or disconnect the PV inverter. To overcome this problem, the use of a dc-chopper braking circuit is proposed in this study. The DC-link braking chopper circuit as shown in Figure 8 is a simple protection scheme that operates by shorting the dc-link through a braking resistor when the dc-link voltage exceeds the threshold value $(725 \mathrm{~V})$ i.e. only when the fault is detected. The braking resistor is calculated according to (15) 


$$
P_{\text {brake }}=\frac{V_{d c}^{2}}{R_{\text {brake }}}
$$

An anti-parallel diode may be connected across the brake resistor to allow for the stray inductance effects when the chopper IGBT is switched off. During normal operation, the switch is open and closes when an over voltage is detected [19].

\subsection{Reactive Current Injection}

In order for the PV system to perform LVRT function during fault caused voltage dips, it has to inject an appropriate reactive current for the particular voltage drop. Post fault the reactive current injection has to be continued for a certain period of time depending on the grid code requirements. According to Figure 9, depicted from the German grid code [6] [20], when the amplitude of grid voltage is between 0.9 p.u and 1.1 p.u, the system is in normal operation and the inverter inject only active current. On the other hand, when the amplitude of grid voltage drops below 0.9 p.u, the inverter control must be switched to LVRT control. Equation (16) shows the piecewise ratio of injected reactive current to the nominal current $\left(i_{q n}\right)$ depending on the level of voltage $\operatorname{dip}[8]$.

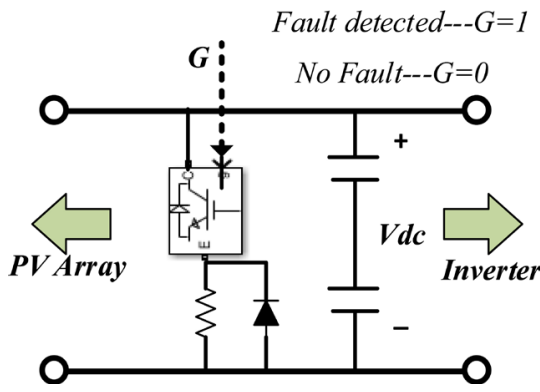

Figure 8. DC-Braking chopper circuit.

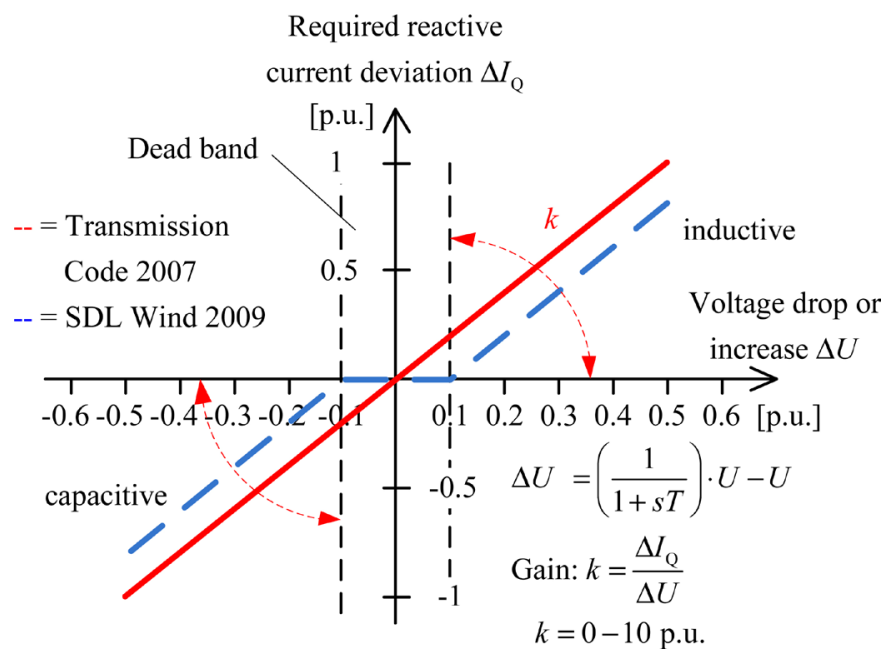

Figure 9. Reactive current injection requirement as per German Grid Code [6] [20]. 


$$
i_{q n}= \begin{cases}0 & \text { case } \mathrm{a}: V_{g}>0.9 V_{g n} \\ 2-2 \frac{V_{g}}{V_{g n}} & \text { case } \mathrm{b}: 0.9 V_{g n} \geq V_{g} \geq 0.5 V_{g n} \\ 1 & \text { case c }: V_{g} \leq 0.5 V_{g n}\end{cases}
$$

where $V_{g}$ and $V_{g n}$ are the amplitude values of the grid voltages during the fault and the normal conditions, respectively. During voltage dip, the inverter should inject the specified reactive power to help voltage recovery based on the LVRT requirements.

\subsection{Active Current Limiting}

Whenever the maximum current rating of PV inverters is exceeded, i.e. the AC current exceeds the operating AC current range and the inverter disconnects from the grid. This is a result of the increased d-components of current in the SRF during grid faults. This increase is because the controller is trying to maintain grid voltage constant and while reducing the injected active power into the grid during fault caused voltage dips. In this case, the q-components of current increase in the SRF increase for the inverter to inject reactive current in order to meet the LVRT requirements [15]. Due to the increase in the $\mathrm{d}$ and q components, the inverter may get disconnected from the grid by over current protection schemes. In order to overcome this issue, the active current (d-component) is limited to within the required limits. Subsequently, the d-component current is a function of the reactive current injected during the fault and the maximum current rating of the inverter as shown in Figure 10. Equation (17), shows the calculation applied for limiting current during grid fault occurrence.

$$
i_{d n}^{*}=\sqrt{\left(1-i_{q n}^{2}\right)} * I_{n}
$$

where $i_{d n}^{*}$ is d-component of the AC current during fault occurrence and In is the nominal maximum operating current of the inverter, $400 \mathrm{~A}$ for the system under study.

During operating conditions, both active and reactive current should not exceed 1.1 times of the nominal current operating value of the inverter, as derived from the equation below [21].

$$
\sqrt{\left(i_{d}^{2}+i_{q}^{2}\right)} \leq 1.1 I_{n}
$$

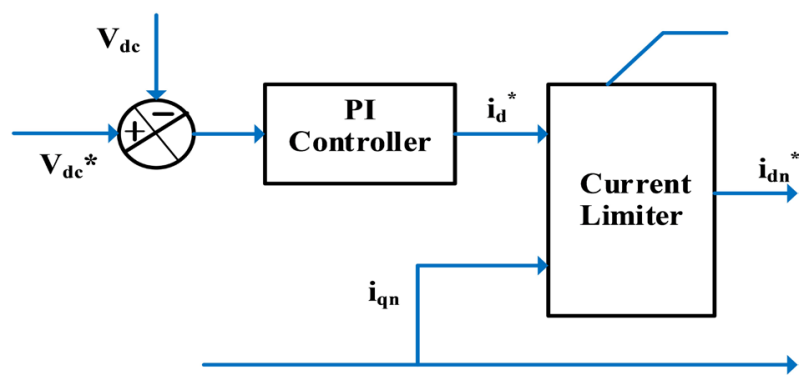

Figure 10. Active Current Limiting control [8]. 
Finally, the allowed active power and injected reactive power during faulty condition can be calculated by:

$$
P=\frac{3}{2}\left(V_{d} i_{d n}^{*}\right) \text { and } Q=\frac{3}{2}\left(V_{q} i_{q n}^{*}\right)
$$

\section{Verification and Simulation Results}

For verification of the effectiveness of the proposed LVRT strategy, dynamic assessment has been performed considering voltage dips caused by both symmetrical and unsymmetrical fault conditions i.e. three phase symmetrical fault (L-L-L) and the single-phase to ground fault (L-G). The instantaneous values of current and voltage are measured at the point of common coupling. Simulation results are displayed in the section below with results within the operating ranges to meet the grid code requirements. The simulations have been carried out at standard test condition (STC) i.e. irradiation, $G$, is $1000 \mathrm{~W} / \mathrm{m}^{2}$ and the temperature, $T$, is $25^{\circ} \mathrm{C}$.

A three-phase fault (worst-case scenario) with $85 \%$ voltage dip is applied along the $15 \mathrm{kV}$ MV line for 0.15 seconds duration ( 0.45 to $0.6 \mathrm{~s}$ ). Figure 11 and Figure 12 show the results without and with the LVRT control strategy on the DC side. It is noted in Figures 12(a)-(c) that all magnitudes keep within

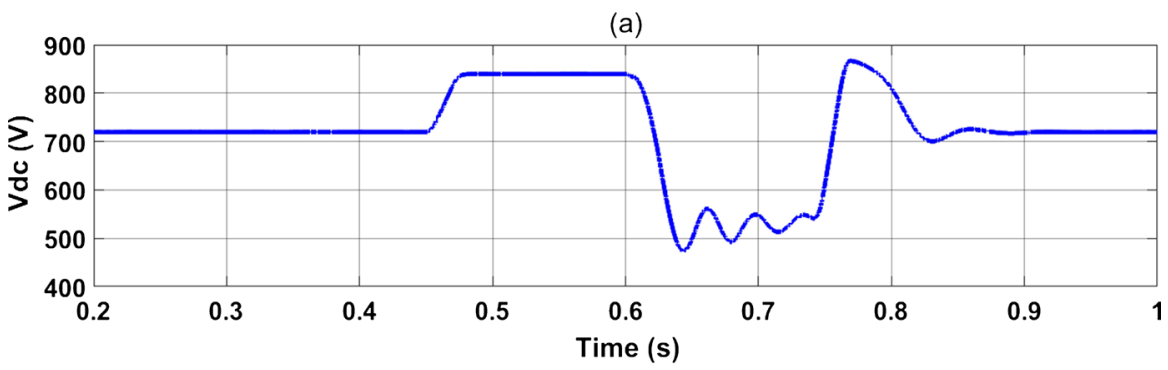

(b)

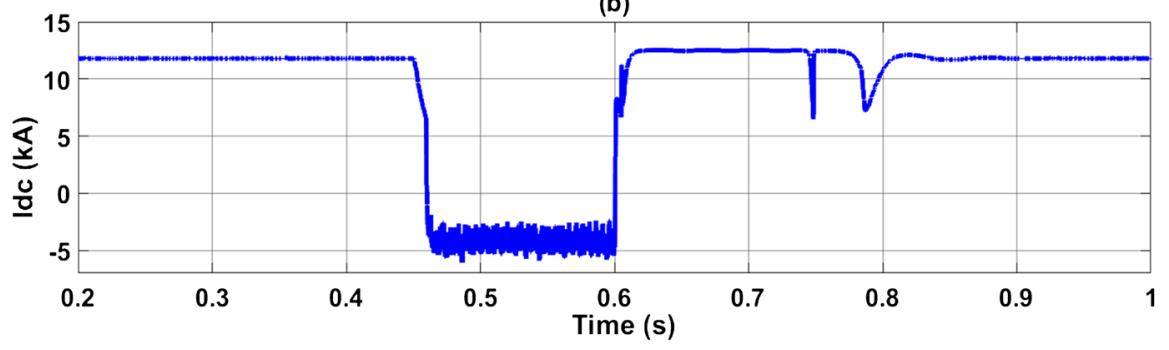

(c)

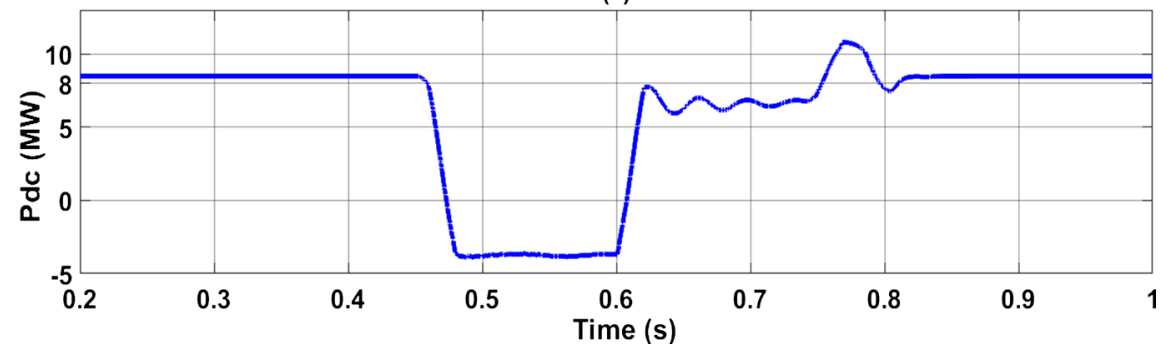

Figure 11. Simulation result without LVRT control during three-phase fault (85\%) voltage dip. (a) DC link voltage, (b) PV array current and (c) PV array output power. 

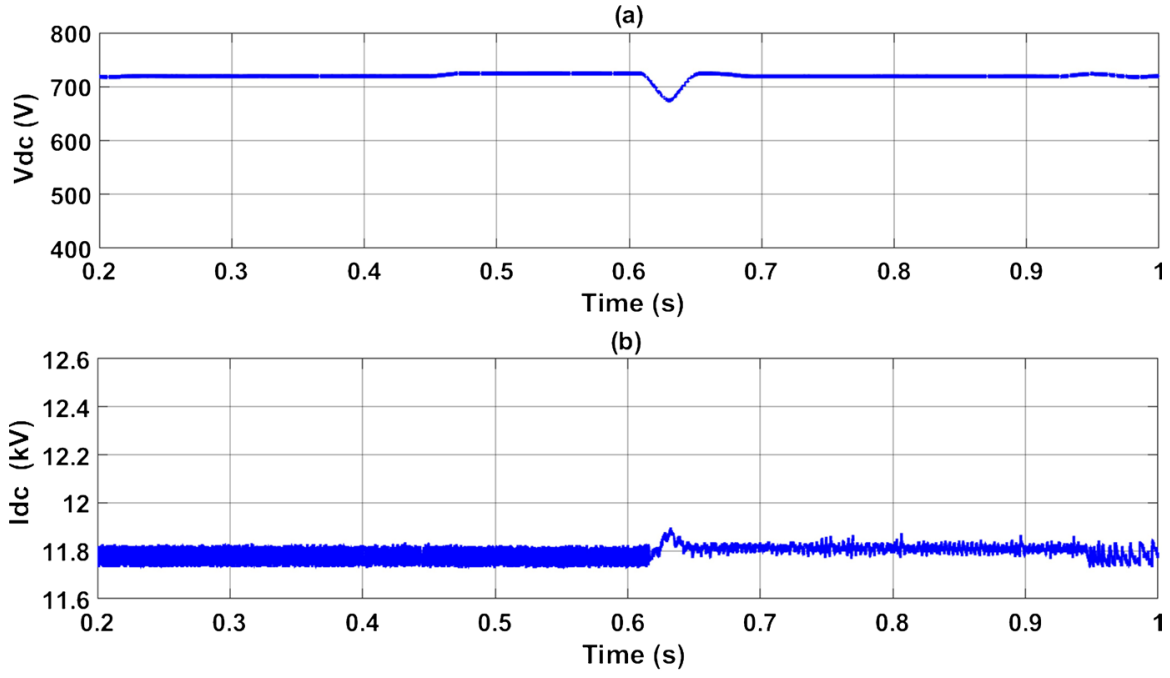

(c)

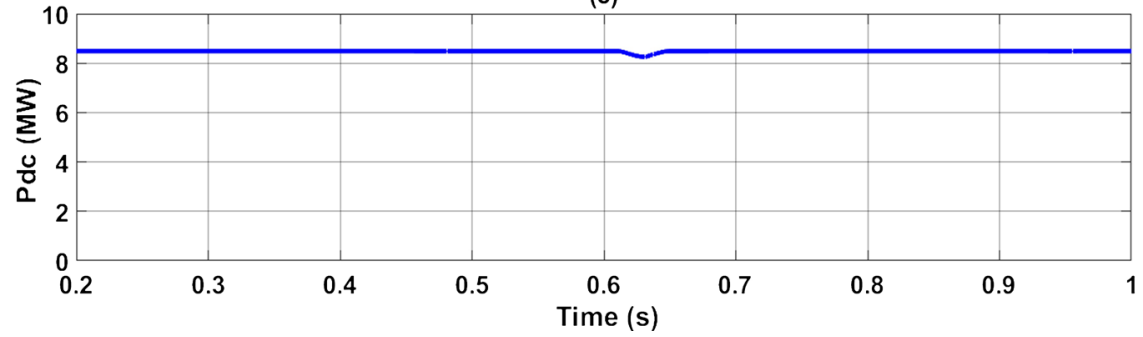

Figure 12. Simulation response with LVRT control during three-phase fault voltage dip. (a) DC link voltage, (b) PV array current and (c) PV array output power.

accepted operating range of the pre-fault values after the fault clearance as opposed to Figures 11(a)-(c) where the value of the DC-link voltage, PV array current and power take a long time to settle to the pre-fault value during fault clearance. This verifies the effectiveness of LVRT in avoiding the excessive DC-link voltage and its associated effects.

In the occurrence of fault, grid code standards require injection of $100 \%$ reactive current into the grid as depicted in Figure 13(d) \& Figure 13(e). This allows the inverter to stay connected and support grid voltage and current recovery as presented in Figures 13(a)-(c).

For the effective study of the current limiting contribution in the proposed LVRT control strategy, a single to ground fault was applied on the $15 \mathrm{kV}$ distribution line for a duration of 0.15 seconds. Figure 14 and Figure 15 show the response results without and with the LVRT control strategy on the AC side respectively. It is observed in Figure 14(b) that the output current exceeds the maximum acceptable current since it greater than the rated current by almost $40 \%$. With the application of the proposed control capability, the output of the limiter will be restricted based on the need for reactive current injection as shown in Figure 15(c). This helps to maintain the grid currents balanced within acceptable operating values i.e. the grid current as measured from the PCC is not greater 1.1 times the nominal inverter current $\left(1.1 \mathrm{I}_{\mathrm{n}}\right)$. This is properly illustrated in Figure 15(b) as opposed to Figure 14(b). 
(a)

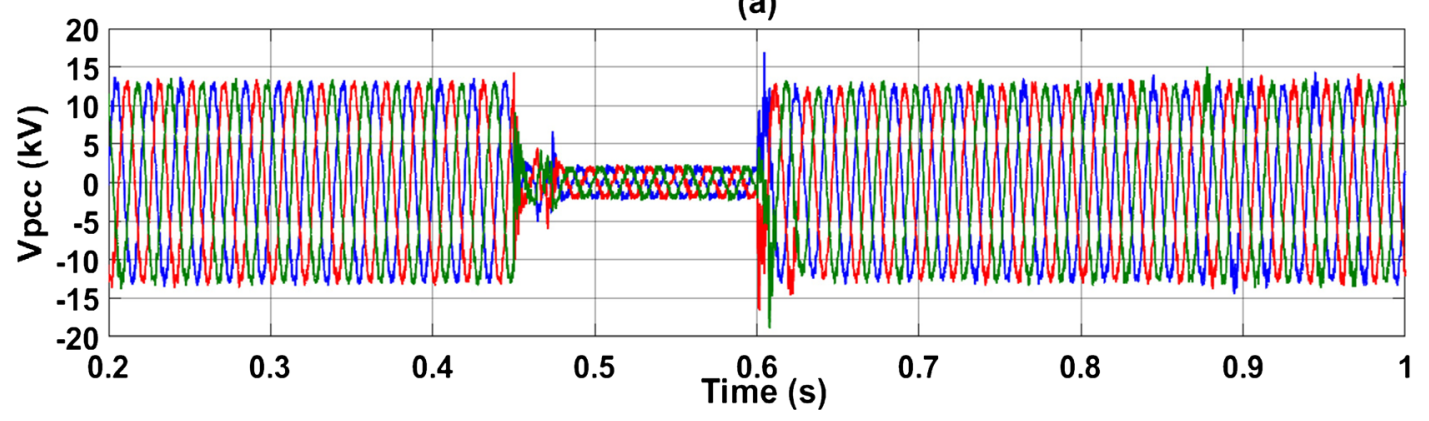

(b)

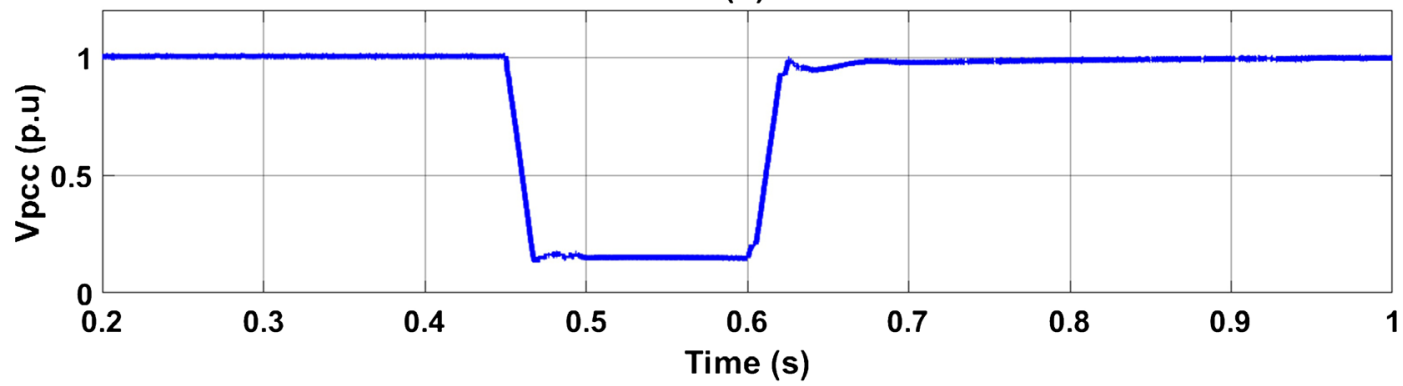

(c)

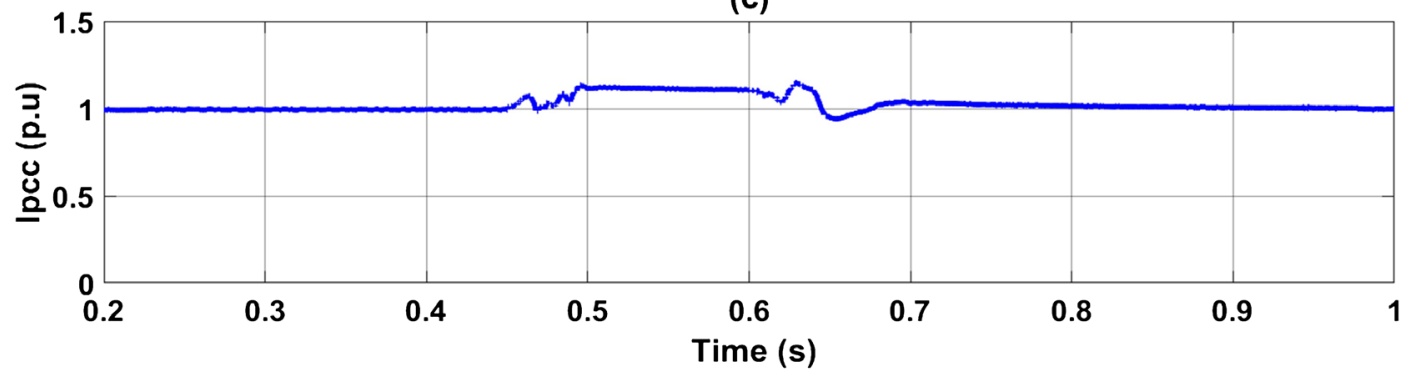

(d)

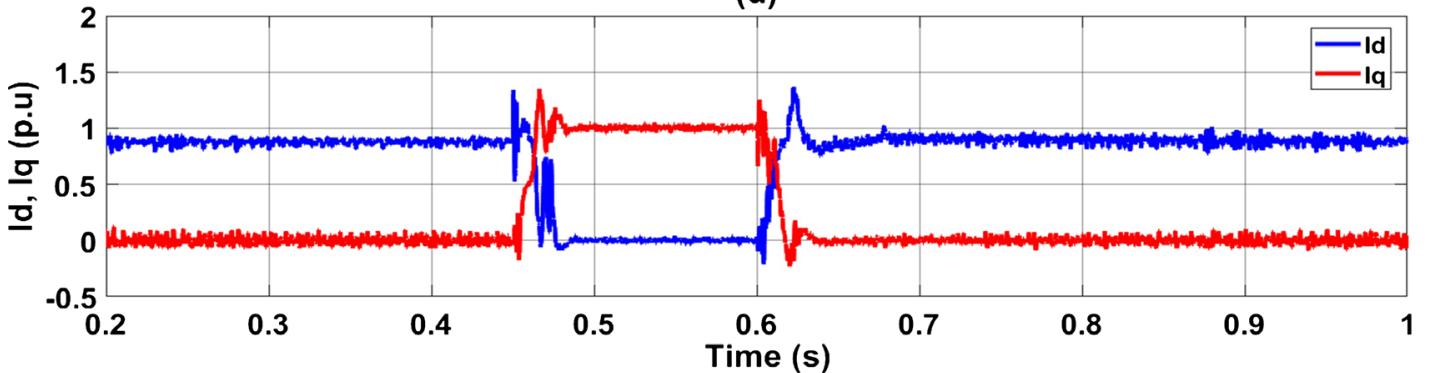

(e)

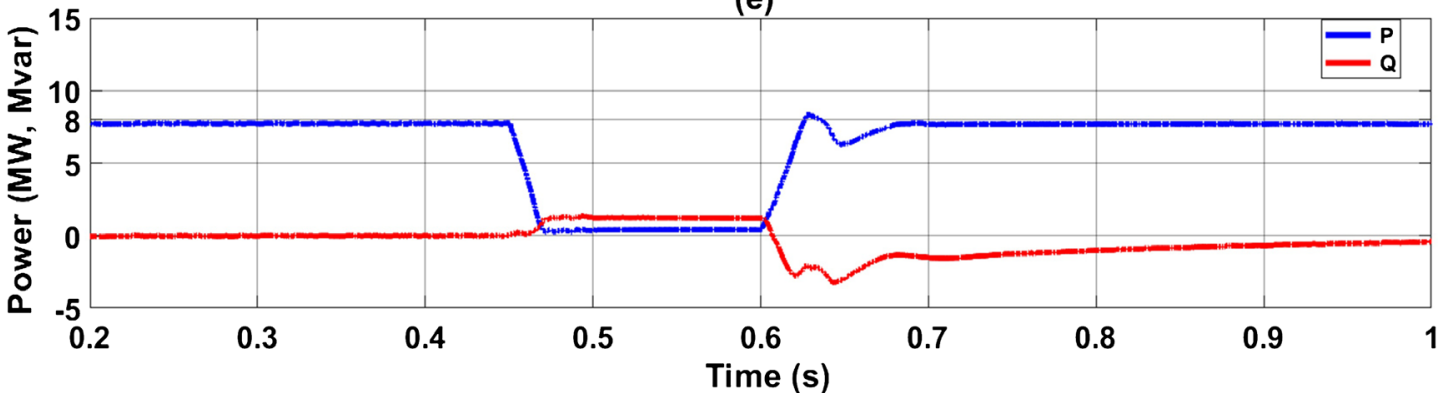

Figure 13. Simulation results with operation of the LVRT scheme during three phase fault (a) grid voltage at PCC, (b) positive sequence of voltage at PCC, (c) positive sequence of current at PCC, (d) active and reactive current components, (e) active and reactive power at PCC. 
(a)

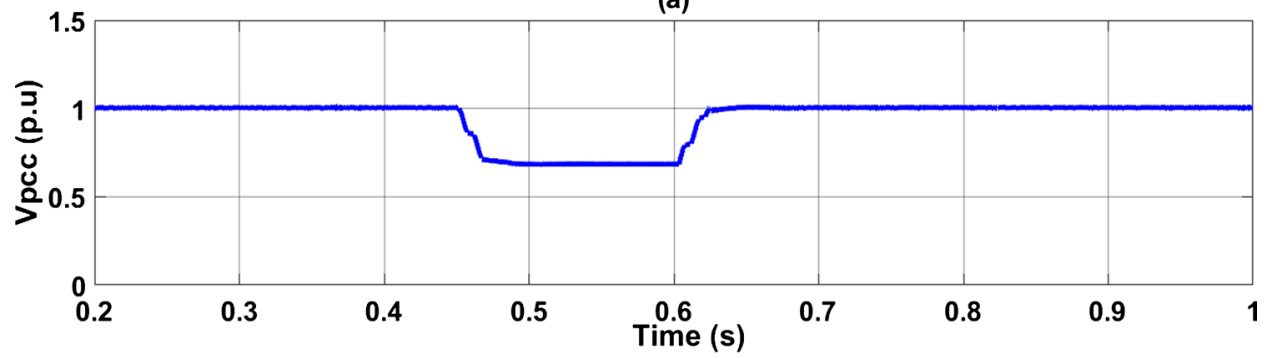

(b)

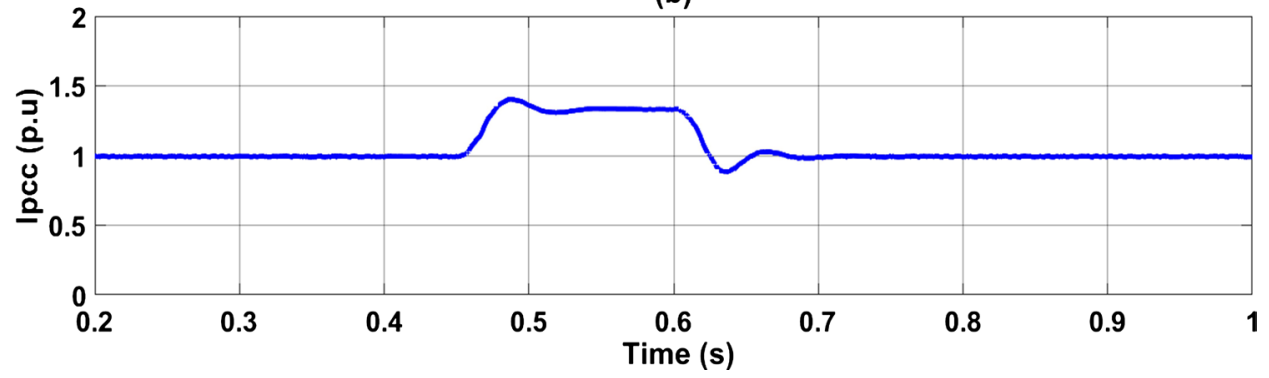

Figure 14. Simulation response with application of SLG fault (30\%) (a) positive sequence of voltage and (b) positive sequence of current at PCC (p.u).

(a)

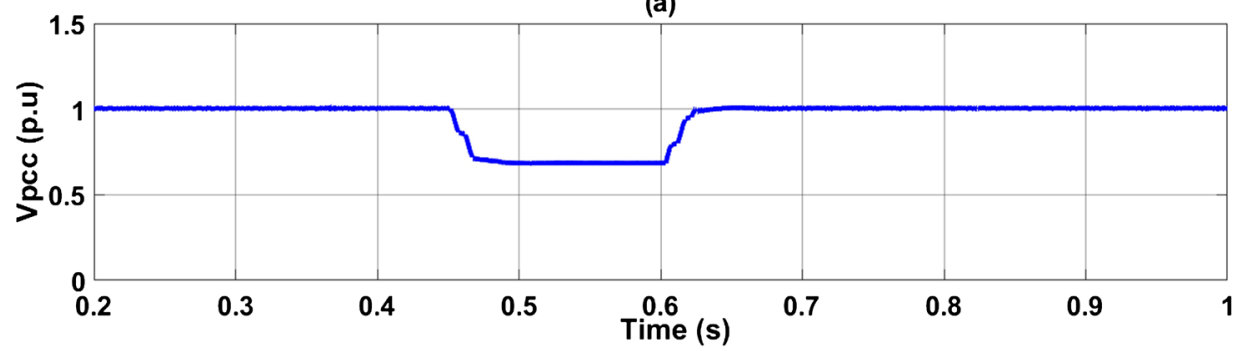

(b)

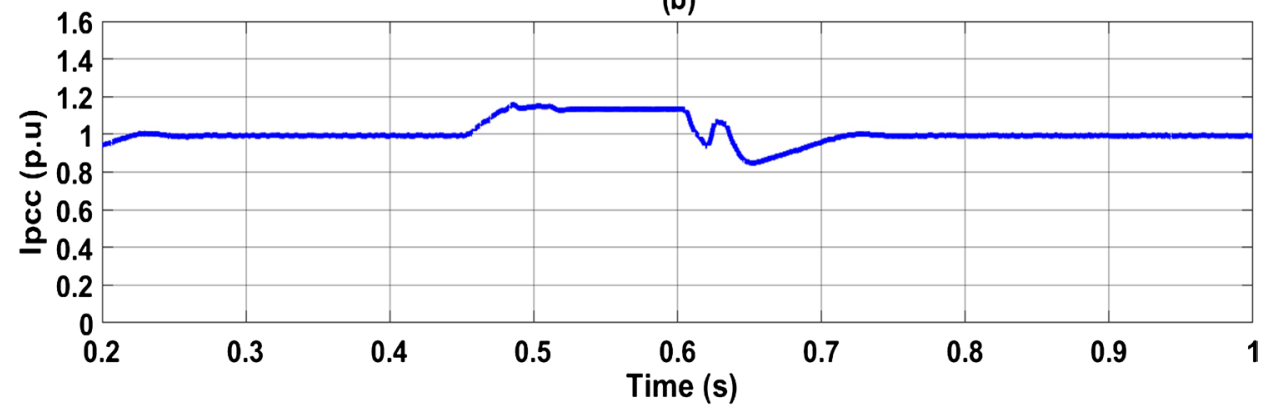

(c)

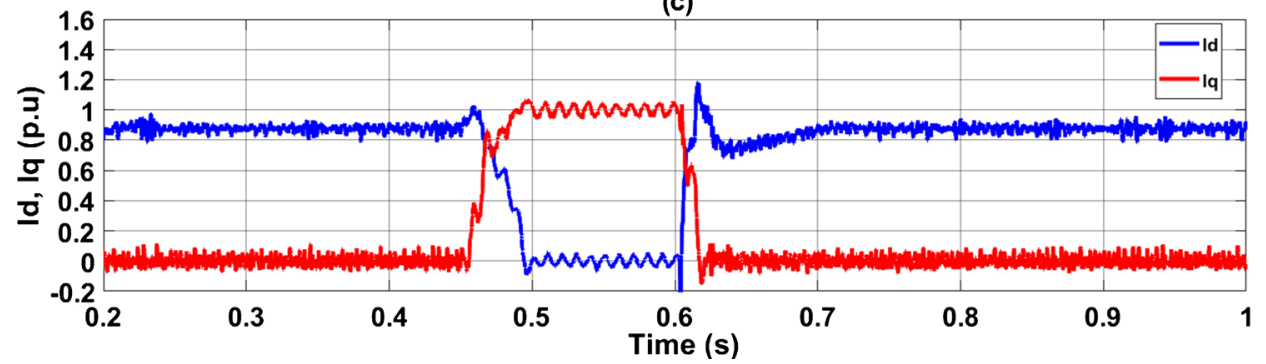

Figure 15. Simulation results of a LVRT control scheme with an unsymmetrical SLG fault (30\%) from the nominal voltage (a) positive sequence of voltage at PCC, (b) positive sequence of the current, (c) active and reactive currrent components. 


\section{Conclusion}

In modern power systems, the GCPSs are designed with the capability to ride through low voltages for grid support. This paper focused on the study of the effectiveness of the combination of the DC chopper and the current limiting technique based on the required reactive current. Simulation results with application of $85 \%$ and $30 \%$ fault caused voltage dips have displayed the effectiveness with fast switching during grid fault operation to suppress the excessive increase of DC voltage, AC current and the excessive energy. In doing so, the inverter remains connected to the system. In conclusion, the proposed control scheme can maximize the voltage support capability of PV plant as well as taking the safety of equipment into consideration.

\section{Conflicts of Interest}

The authors declare no conflicts of interest regarding the publication of this paper.

\section{References}

[1] Al-Shetwi, A.Q. and Sujod, M.Z. (2018) Grid-Connected Photovoltaic Power Plants: A Review of the Recent Integration Requirements in Modern Grid Codes. International Journal of Energy Research, 42, 1849-1865. https://doi.org/10.1002/er.3983

[2] Liang, X. (2017) Emerging Power Quality Challenges Due to Integration of Renewable Energy Sources. IEEE Transactions on Industry Applications, 53, 855-866. https://doi.org/10.1109/TIA.2016.2626253

[3] Favuzza, S., Spertino, F., Graditi, G. and Vitale, G. (2004) Comparison of Power Quality Impact of Different Photovoltaic Inverters: The Viewpoint of the Grid. IEEE International Conference on Industrial Technology, Hammamet, 8-10 December 2004, 542-547. https://doi.org/10.1109/ICIT.2004.1490350

[4] Al-Shetwi, A.Q., Sujod, M.Z. and Ramli, N.L. (2015) A Review of the Fault Ride through Requirements in Different Grid Codes Concerning Penetration of PV System to the Electric Power Network. ARPN: Journal of Engineering and Applied Sciences, 10, 9906-9912.

[5] Marinopoulos, A., Papandrea, F., Reza, M., Norrga, S., Spertino, F. and Napoli, R. (2011) Grid Integration Aspects of Large Solar PV Installations: LVRT Capability and Reactive Power/Voltage Support Requirements. IEEE PES Trondheim PowerTech, Trondheim, 19-23 June 2011, 1-8.

[6] Troester, E. (2009) New German Grid Codes for Connecting PV Systems to the Medium Voltage Power Grid. 2nd International Workshop on Concentrating Photovoltalic Power Plants: Optical Design, Production, Grid Connection, 1-4.

[7] Kumar Hota, P. (2016) Fault Analysis of Grid Connected Photovoltaic System. American Journal of Electrical Power and Energy Systems, 5, 35-44. https://doi.org/10.11648/j.epes.20160504.12

[8] Al-Shetwi, A.Q., Sujod, M.Z. and Blaabjerg, F. (2018) Low Voltage Ride-Through Capability Control for Single-Stage Inverter-Based Grid-Connected Photovoltaic Power Plant. Solar Energy, 159, 665-681.

[9] Worku, M.Y. and Abido, M.A. (2015) Grid-Connected PV Array with Supercapacitor Energy Storage System for Fault Ride through. IEEE International Conference 
on Industrial Technology (ICIT), Seville, 17-19 March 2015, 2901-2906. https://doi.org/10.1109/ICIT.2015.7125526

[10] Lin, F.-J., Lu, K.-C., Ke, T.-H., Yang, B.-H. and Chang, Y.-R. (2015) Reactive Power Control of Three-Phase Grid-Connected PV System during Grid Faults Using Takagi-Sugeno-Kang Probabilistic Fuzzy Neural Network Control. IEEE Transactions on Industrial Electronics, 62, 5516-5528. https://doi.org/10.1109/TIE.2015.2407851

[11] Al-Shetwi, A.Q. and Sujod, M.Z. (2016) Modeling and Dynamics Study of Large Scale PV System Connected Malaysian Grid under Different Fault Conditions. International Conference on Advances in Electrical, Electronic and Systems Engineering (ICAEES), Putrajaya, 14-16 November 2016, 14-16.

[12] Villalva, M., Gazoli, J. and Filho, E. (2009) Comprehensive Approach to Modeling and Simulation of Photovoltaic Arrays. IEEE Transactions on Power Electronics, 24, 1198-1208. https://doi.org/10.1109/TPEL.2009.2013862

[13] Diode, T., Using, M. and Simulink, M. (2015) Modeling and Simulation of Photovoltaic Module and Array Based on One and Modeling and Simulation of Photovoltaic Module and Array based on One and Two Diode Model Using Matlab/Simulink. Energy Procedia, 74, 864-877.

[14] Salmi, T., Bouzguenda, M., Gastli, A. and Masmoudi, A. (2012) MATLAB/Simulink Based Modelling of Solar Photovoltaic Cell. International Journal of Renewable Energy Research-IJRER, 2, 6.

[15] Jaalam, N., Rahim, N.A., Bakar, A.H.A. and Eid, B.M. (2017) Strategy to Enhance the Low-Voltage Ride-Through in Photovoltaic System during Multi-Mode Transition. Solar Energy, 153, 744-754. https://doi.org/10.1016/j.solener.2017.05.073

[16] Kuran, K. and Reicher, D. (2016) The Bright Continent: The Outlook for Utility-Scale and Commercial \& Industrial Solar Projects in East Africa.

[17] Kim, G.S. and Lee, K.B. (2012) Fault Diagnosis and Fault-Tolerant Control of a DC-Link Voltage Sensor for PV Inverters. 2012 IEEE 7 th International Power Electronics and Motion Control Conference, Harbin, 2-5 June 2012, Vol. 2, 1408-1412.

[18] Mashaly, S. and Abdallah, M.H. (2017) Low Voltage Ride through and Fault Ride through Capability of $40 \mathrm{kw}$ PV Model Grid Connected. 2016 Saudi Arabia Smart Grid Conference, Jeddah, 6-8 December 2016, 1-6.

[19] El Makrini, A., El Karkri, Y., Boukhriss, Y., El Markhi, H. and El Moussaoui, H. (2017) LVRT Control Strategy of DFIG Based Wind Turbines Combining Passive and Active Protection. International Journal of Energy Research, 7, 1258-1269.

[20] Neumann, T. and Erlich, I. (2012) Modelling and Control of Photovoltaic Inverter Systems with Respect to German Grid Code Requirements. 2012 IEEE Power \& Energy Society General Meeting, Manchester, 22-26 July 2012, 1-8. https://doi.org/10.1109/PESGM.2012.6345310

[21] Al-Shetwi, A.Q. and Sujod, M.Z. (2017) Modeling and Control of Grid-Connected Photovoltaic Power Plant with Fault Ride-Through Capability. Journal of Solar Energy Engineering, 140, 1-8. https://doi.org/10.1115/1.4038591 


\section{Nomenclature}

$\begin{array}{ll}V_{n} & \text { Nominal voltage } \\ D C & \text { Direct current } \\ A C & \text { Alternating current } \\ M W & \text { Mega Watt } \\ k V & \text { Kilovolt } \\ V A & \text { Volt-ampere } \\ V_{d c} & \text { DC link voltage } \\ I_{p V} & \text { PV array current } \\ V_{p V} & \text { PV array voltage } \\ V_{g} & \text { Grid voltage at the point of common coupling } \\ I_{g} & \text { Grid current at the point of common coupling } \\ L_{f} & \text { Inductance of the harmonic filter } \\ C_{f} & \text { Capacitance of the harmonic filter } \\ R_{d} & \text { Damping resistor } \\ I_{L} & \text { Load voltage } \\ V_{L} & \text { Load voltage } \\ T h d & \text { Threshold } \\ p . u & \text { Per unit representation } \\ I G B T & \text { Insulated gate bipolar transistor }\end{array}$

